\title{
Relationship Between Innovation and Organizational Performance in Construction Industry in Malaysia
}

\author{
Megat Zuhairy Megat Tajuddin ${ }^{1, *}$, Hadijah Iberahim $^{2}$, Noraini Ismail ${ }^{3}$ \\ ${ }^{1}$ Electrical Engineering Branch, Public Works Department, Malaysia \\ ${ }^{2}$ Faculty of Business \& Management, Universiti Teknologi MARA, Malaysia \\ ${ }^{3}$ School of Management \& Business, Manipal International University, Malaysia
}

Copyright (C) 2015 by authors, all rights reserved. Authors agree that this article remains permanently open access under the terms of the Creative Commons Attribution License 4.0 International License

\begin{abstract}
This paper aims to discuss the relationship between innovation and organizational performance in the construction industry. In Malaysia, the construction industry is known to be one of the industries that contribute significantly towards her economic growth. This contribution, more often than not is associated with the amount of innovation invested by organizations in the industry. The industry's innovation performance currently is reported to be amongst the lowest as compared to the others, which inspired this study to unveil the extent influence of innovation on performance. The instruments in measuring innovation and organizational performance specific to the construction industry were developed by adapting measures introduced by several scholars in these fields. While innovation is represented by innovative design solution, innovative project practices and advanced technology utilization, organizational performance is represented by project and business performance. Contractors and consulting companies were the sampling frame of this study and the samples were selected based on a stratified sampling method to gauge representation of the different groups in the population. The results revealed that principally innovation is significantly positive in influencing organizational performance. Nevertheless, innovative design solution and advanced technology dimensions were insignificant in influencing project performance and business performance respectively.
\end{abstract}

Keywords Innovation, Construction Industry, Organizational Performance

\section{Introduction}

In Malaysia, the construction industry has contributed significantly in establishing the infrastructure required for socioeconomic development and contributing directly to economic growth. Ibrahim, Roy, Ahmed, and Imtiaz, [1] reported that the essential elements of a healthy, functioning economy that are driven by the educational institutions, government offices, tourist attractions, transportation infrastructure, housing, commercial property are built and maintained by the construction industry. The Economic Transformation Program (ETP) announced by the Prime Minister of Malaysia unveiled 131 entry point projects and 60 business opportunities that would help boost Malaysia's gross national income (GNI) to US\$523 billion in 2020 from US\$188 billion in 2009. Out of these projects, construction industry has the largest share entailing 60 percent of the total budget [2].

Malaysia's construction industry registered a growth of 5.8 percent in 2009 , and subsequently 8.7 percent in 2010 and recently at 11.2 percent in 2013 . When translated these percentages into projects awarded in the 9th Malaysia Plan, around 26,300 projects were awarded valued at RM380 billion compared to the 8th Malaysia Plan which registered 25,700 projects valued at RM255 billion. RM230 billion development funds and RM20 billion facilitation funds have been allocated in the $10^{\text {th }}$ Malaysia Plan which covers the period from 2011 to 2015 . These allocations have created the impetus in driving demand for the construction industry. Out of the RM230 billion for development expenditure, 60 percent or RM138 billion is expended in physical development undertaken by the industry. The RM20 billions facilitation funds are expected to attract private sector investments worth at least RM200 billions of which a major portion would be involving the construction development projects [3] which include mega projects such as the Greater KL project and the RM36 billion Mass Rail Transit project. In addition, Malaysia's construction industry has established about 64,000 contractors and employs 800,000 workforces that include the professionals, supervisors, skilled and unskilled workers [4].

In terms of Malaysia's GDP, construction industry only accounts for less than 5 percent; albeit its performance has great influence on the overall economic growth. Ibrahim et al. [1] portrays the construction industry as an "essential growth 
enabler" due to its extensive linkages and integration with other industries namely the manufacturing industry that supplies construction materials such as basic metal, cement, electrical machinery etc. For example in 1998, when the construction industry experienced a sharp downturn, the metal industry in Malaysia saw a 35.6 percent drop in output [1]. Therefore, it is fundamental for the industry to sustain its growth and attain greater performance as it has spillover effect on other industries.

Malaysia has strategically emphasized innovation as the key factor for greater growth and recognizes the importance of innovation as the catalyst for the country's long term success. This is also highlighted in the ETP that recognizes the significance of innovation as the impetus in achieving Malaysia's Vision 2020. Barlow [5] and Doree [6] suggest that construction industry needs to be dynamic and countries need to setup reform programs to improve the industry's performance where one of the goals of the programs is to enhance innovation. The Construction Industry Development Board (CIDB) echoed this notion by underlining innovation as one of the strategic thrust in the Construction Industry Malaysia Plan (CIMP) aiming for industry's superior performance [4]. The CIMP that strategizes industry's goals for the year 2006 to 2015 denotes the importance of innovation through research and development and through adopting new construction methods. Malaysia's aim of becoming a developed country and a high income economy status by the year 2020 can be realized by emphasizing towards the industry's improved and greater performance through innovation.

While there are many researches on the field of innovation available, study within the perspective of the construction industry are limited. In fact, according to Sexton and Barrett [7], the study of innovation has been perceived as being at the nascent stage in the construction and build environment field. A study was conducted by Panuwatwanich, Steward and Mohamed [1] on the determinants of innovation and business performance in Australian architectural, engineering and design (AED) firms as they claimed that there were no known study on an empirical investigation of the cause-and-effect relationships between innovation determinants and the innovation outcome within the AED firm context. Steward, Mohamed and Marosszeky [9] examined IT innovation in the Australian construction industry and Salter and Gann [10] explored on sources of ideas for innovation engineering design. In order to achieve that, they conducted a case study on a leading international engineering consultancy company in the United Kingdom (UK).

Within the ASEAN region, a study was conducted by Wan, Ong and Lee [11] to identify the factors that have influence on innovation in Singaporean firms. The study examined innovation across all major industry sectors, one of which was the construction sector and revealed that decentralized structure; presence of organizational resources for innovation; belief that innovation is important; willingness to take risks; and willingness to exchange ideas were identified to have significant positive influence on innovation. On the local ground, despite the attentiveness on the importance of construction industry to the economy and the significance of innovation in contributing to the competitive edge of an organization, study on this subject is still at its infancy stage where the only known studies were conducted by Ismail [12] and Jaafar, Ramayah, Abdul-Aziz, Saad [13]. Ismail [12] examines the determinants (learning organizational culture and organizational creative climate) for innovation in local organizations and multinational corporations (MNCs) in Malaysia. Jaafar et al. [13] explores on the technology readiness among managers of Malaysian construction firms particularly in the aspect of technology innovation.

The topic of innovation has been previously explored extensively out of the country. Most of these studies were context specifics, their implementation and implication are usually limited to countries and the operating environment where these studies were conducted. The lack of effort to contextualize the findings into construction industry in the local context has advocated that there be a study aiming to overcome the existing gap. Given the above background, it is crucial to explore better understanding in the aspect of enhancing construction industry's performance which demands for dynamic and innovative strategies in contributing towards greater growth. The fact that there are gaps and concerns in the construction industry particularly in the context of industry performance and innovation, an empirical study on the subject matter is mooted. This paper aims to explore the relationships between innovation and organizational performance in Malaysia's construction organizations.

\section{Innovation in Construction Industry}

In the current global economic environment, it is vital for the construction industry to keep pace with the rapid changes of the technology and economic model that the world is heading towards. However, literatures in innovation indicate that construction industry has often been criticized for resisting change and for failing to adopt innovative approaches to improve performance [14]. According to the National Endowment for Science, Technology and the Arts (NESTA) [15], the construction industry is among the six "low innovation" sector along with oil production, retail banking, legal aid services, education and the rehabilitation of offenders sectors. In addition, the Third UK Community Innovation Survey conducted in 2004 revealed that construction was the worst performing industry in innovation in comparison with 11 other industries [16]. A survey conducted by the Australian Bureau of Statistics on innovation in Australian industries indicates that the construction industry had one of the lowest proportions of innovating businesses comparable to mining businesses and had fallen behind other industries such as manufacturing, electricity, gas and water supply and communications [17]. 
Nevertheless, the indicative low innovation level of the construction industry by past researchers, according to Panuwatwanich [8], is considered not conclusive and demands for more in-depth studies. This is contributed by diverge views of scholars in defining and identifying innovation, which are distinct and in some cases irrelevant across different industries. For example, in dynamic industries such as pharmaceuticals, electronics, biotechnology and IT, product innovation is essential which demands organizations for continuous product development in order to succeed in the intense competition and fast product evolution environment. These types of industries are considered as research intensive industries that adopt indicators such as Research and Development (R\&D) expenditures and capital investments, publications and patents as the common measures for innovation [18].

On the contrary, construction industry is regarded as a highly fragmented, loosely coupled, complex and non-research intensive industry and innovation is established within a project implementation that require involvement of varying combinations of large and small organizations from across the supply chain spectrum [19]. This includes a broad representation of key players in the industry particularly among manufacturers and service providers in the process of transforming materials, knowledge and processes into buildings and infrastructures. Adopting the traditional measures of innovation in a dynamic industry such as manufacturing will not reflect the actual representation of the construction industry. This is because innovation in construction usually does not involve R\&D investments and introduction of new products and processes in the form of publications and patents. Hence, if such measure were used in the construction industry, the outcome might result in low level of innovation. This view is supported by Aouad, Ozorhon and Abott [20] who argue that innovations in construction industry are project based and not able to be indicated as formal R\&D expenditure and innovations are neither patented nor trademarked. Hence, employing the appropriate measures for assessing innovation will provide the real depiction of innovation in the construction industry. In addition, while manufacturing innovations for example, involve resources within the organization itself for both product and process innovation, construction innovations requires involvement of different parties from various organizations engaged directly in the construction projects. For these reasons, much of the innovation in construction remains "hidden", as it is co-developed at the project level and not at the organizational level. Project teams disband upon completion of projects whilst innovation typically remains within the project per se. Hence, in the construction industry, evaluating innovation at project level will provide a more objective measurement as compared to the innovation at organizational level.

The organizational context of construction innovations as Slaughter [21] pointed out differs significantly from a great portion of manufacturing innovations. This is supported by Blayse and Manley [22] who state that construction is partly manufacturing (materials, components, and equipment) and partly services (engineering, design, surveying, consulting, and management). Similarly, Peansupap [23] categorizes innovation in construction industry into three; (1) Innovation in materials, equipment and methods (2) Management innovation and (3) Information Technology (IT) innovation. The first category refers to technical innovation, which can be either technical product or technical process innovation. Technical product innovation includes concrete materials, construction techniques, Industrialized Building System (IBS), robotics construction equipment etc. This type of innovation can be either adopted by organizations or created within a particular construction project. For example, a technical project setback in construction installation has triggered a construction organization to develop an innovative construction method. A project delay may generate an innovative and efficient technique devised from existing resources.

Management innovation on the other hand is reflected by techniques and principles that are adopted to facilitate the process of management and administration of construction organization and construction projects. Value engineering, Total Quality Management (TQM) and Lifecycle Costing are some of the examples of management innovation. Finally Information Technology (IT) innovation is characterized by the adoption of hardware and software that are used to facilitate for a more effective and efficient construction project implementation such as the Building Information Modeling (BIM), online project procurement system, project management application, Radio Frequency Identification (RFID), material testing, etc.

Evidences from past researches indicate that construction innovation is process and organization based and often characterized by the widespread adoption of new practices as a result of advances in technological and business processes [21]. This is supported by the case study conducted by Gil, Miozzo and Massini [24] on Heathrow airport's T5 project, which stress that innovation hinges on technology adoption decisions. Panuwatwanich et al. [8] adopted innovation diffusion outcomes namely innovative design products, innovative design practices and advanced technology utilization as the measurement for innovation in the architectural and engineering design sector. The innovative design product is measured by elements like recognitions and awards received, flexibility for change, and minimum environmental impact. The innovative design practices elements include value management, value engineering, life cycle costing and sustainable design. Examples of the elements for the advanced technology utilization dimensions are design drafting and development, integration of design information and remote collaboration.

In addition, Qi, Shen, Zeng and Jorge [25] highlight the increasing concerns on environmental degradation which has triggered the need for innovative construction environmental practices. It is suggested that construction sustainable design is included as one of the innovative products of the construction industry. Proactive environment strategies and 
practice adoption by project managers in mitigating the environmental impact by the company's activities is considered as one of the innovative efforts. Other studies listed several innovative initiatives such as the application of environmental friendly equipment and technologies and the investment on the environmental protection measures in construction practice [26]. In this field of study, scholars usually define such effort interchangeably between green construction and sustainable development practices. Both terms in the context of construction industry are described as the responsibility to minimize the impact of industry's activities on environment and society. Sustainable or green related innovations include retrofitting solar, passive principles to older buildings, employing environmental awareness, surface-water management, employment of lighter and more environmentally friendly materials, and use of advanced building products.

\section{Organizational Performance in Construction Industry}

Organizational performance has been the subject of studies across various industries around the world. As globalization offers both opportunities and challenges; organizations are forced to make dramatic improvements not only to compete and prosper but merely to survive [27]. Consequently, achieving superior performance is the ultimate goal of every organization [28]. Thus, measuring and analyzing organizational performance play an important role in turning organizational goals to reality [29]. Moreover, when attempting to improve an industry as a whole, understanding the aspect of performance of the organization within the industry is imperative.

Organizational performance can be defined in various forms that fit in relation to the perspective and context of a study. Robinson, Anumba, Carrillo and Ghassani [30] argue that performance should be reflected by both financial and non-financial performance. They identify market share, new customers, return on capital employed, return on investment, number of new customers and sales as the indicators for financial performance. The non-financial measures are reflected by the customer characteristics, the impact of business on society, employee or people characteristics, product performance and process performance. Gunday, Ulusoy, Kilic, and Lutfihak [31] support the approach in adopting both financial and non-financial aspects in measuring organizational performance but further divide them into four categories namely innovative performance, production performance, market performance and financial performance. Such approach provides a comprehensive representation on the overall performance of an organization. Innovative performance is quantified based on the quality and quantity of new products and services introduced within an identified time frame. Production performance is defined based on production flexibility, delivery speed and cost and conformance quality. Market performance is measured based on total sale, market share and customer satisfaction. The measurement of Return on Sales (ROS), Return on Asset (ROA), cash flow and organization profit are categorized in the financial performance. The first two performance categories (innovative and production) identified by [31] can be considered to represent the non-financial aspects while the last two categories (market and financial) are the financial characteristics of performance.

These aspects of financial and non-financial approach in defining organizational performance can also be adopted in the construction industry. In the study conducted by Robinson et al. [30], 85 percent of construction engineering organizations in United Kingdom (UK) used the combination of financial and non-financial measures to reflect organizational performance. The fragmented nature of the construction industry that requires involvement of various parties in completing a construction project has directed the need for evaluating the final product as the indicator for organizational performance instead of examining the performance of every party involved. Construction project is the product of the construction industry and therefore, project performance which falls in one of the non-financial categories (product performance) defined by [31] is suggested as one of the suitable dimensions for the performance indicator for construction industry in determining the overall organizational performance.

\subsection{Project Performance}

Scholars defined project performance in several perspectives. For instance, the nine essential knowledge and management areas proposed by the Project Management Body of Knowledge (PMBOK) [32] to describe project management can be adopted as the proxy measure of project performance. The nine knowledge and management areas are (1) Integration, (2) Scope, (3) Cost, (4) Quality, (5) Human Resource, (6) Communications, (7) Risk, (8) Procurement (9) Time and (10) Stakeholder. However, according to Westerveld [33] the PMI's definition of project management is unclear and it is difficult to link areas and project situations in order to reflect the project performance. Furthermore, some of the areas defined are intricate to be quantified (such as the project integration and procurement) due to their subjective and intangible nature. For example, management of project integration involves collection of processes required to ensure that the various elements of the projects are properly coordinated. In order to measure the level of integration demands for evaluation of every element in the construction project implementation.

Nevertheless, Atkinson [34], suggests that project performance in project management perspective to be defined based on the 'Iron Triangle' project success criterion; Cost-Time-Quality. These three criteria are part of the knowledge and management areas defined by PMI and have been identified and discussed in almost every literature on project performance namely by Belassi and Tukel [34]; 
Hatush and Skitmore [35]; and Blayse and Manley [22]. Whilst cost can be measured based on the extent of deviation of the project cost from the initial project budget, quality is measured based on the quantity of non-conformance items detected during the project implementation. Quality is usually reflected by the extent of the project implementation in accordance to the set technical specifications and standards [36]. On the other hand, time is measured based on the timely completion of the project as compared to the projection completion date. However, Low and Chuan [37] argue that the 'Iron Triangle' conventional measures only reflect the project management performance and do not indicate the actual representation of the overall project performance. According to Almahmoud, Doloi and Panuwatwanich [38] who conducted a study on construction projects in Saudi Arabia that there are some other important criteria involved. They included in their study three additional measurement criteria for project performance scope; safety; and satisfaction. The scope criterion reflects the amount or value of the project variation orders. Safety is defined as the extent of safety of the project based on number of accidents or the number of non-conformance safety standard's reports. Satisfaction is reflected by customer satisfaction index which indicates the level of customers' satisfaction on the overall project. In addition, according to Ibrahim et al. [1] besides improving the three iron-triangle aspects of performance, the construction industry shall also focus on health, safety and environment of construction projects. These factors contribute to a more comprehensive representation of the performance of a construction project. The inclusion of these additional criteria for measuring construction project performance is supported by numerous scholars such as Kometa, Olomolaiye and Harris [39]; Dulaimi, Ling, and Ofori [40]; Chan and Chan [41]; Nudurupati, Arshad and Turner [42].

Taking into account these additional aspects of project performance measure in construction industry, Chan and Chan [41] introduced a consolidated framework for measuring project performance, or as they named it as project success of construction project which combines the project performance measures in construction industry proposed by researchers over the last few decades. The framework provides a comprehensive representation of the project performance that includes every aspect in project implementation namely quality, time, cost, health and safety, participant satisfaction, user satisfaction, environmental performance and commercial value. This framework establishes a complete source of performance measurement dimensions in the construction industry. The project performance criteria developed by Chan and Chan [41] have been adopted by Pinto, Slevin and English [43] in their study on large construction projects in Canada. Hence, it is suggested that these comprehensive measures to be used in assessing construction project performance for this study.

\subsection{Business Performance}

The identified project performance measures only explore on the aspect of the non-financial perspective of the organizational performance. There are researches conducted by several scholars that adopt business performance as the performance indicator in the context of financial perspective in the construction industry. For instance, research by Aragon-Correa, Garcia Morales and Cordon-Pozo [44] evaluate organizations' performance measures as return on assets, return on internal resources, and sales growth in their main products or services and markets; using main competitor comparison as the measuring scale. The study by Panuwatwanich et al. [8] define the business performance dimension in AED firms by the elements of profit, turnover growth, market share, ability to attract new clients, and ability to gain repeat business in addition to the project performance measure which represented by the product delivery (time, cost and quality) and client satisfaction.

Nudurupati et al. [42] suggests that the business performance measurement in manufacturing industry can also be adapted in the construction industry which includes among others gross profit, return on asset, return on sales and sales revenue. Robinson et al. [30] identify financial measures as market share, return on capital employed, return on investment, numbers of new customers and sales. Other studies in the context of construction industry that adopt business performance as the performance measures are those by Cheng, Ryan and Kelly [45]; Gunday et al. [31]; and Beach, Webster and Campbell [45].

It is indicated that both financial and non-financial measures have been adopted by scholars in their attempts in examining organizational performance in the construction industry. The financial measures identified by scholars are considered relevant across many industries. In addition, project performance has been adopted by several scholars $[34,38,41,43]$ as the measures in the context of non-financial performance. Having both financial and non-financial aspects of performance will provide a more pragmatic outcome in explaining organizational performance specific to the construction industry. Hence, in this study organizational performance will constitute these two dimensions (1) project performance and (2) business performance. While the project performance examines the performance of the construction project implementation, business performance looks in the business aspect of the particular construction organizations.

\section{The Relationship Between Innovation and Organizational Performance}

Many scholars have endorsed the importance of innovation in determining the performance of an organization $[8,18,44,47,48]$. These studies were done across different economic sectors around the globe and relate innovation to industries' performance that further recognized the importance of innovation for an economy's success. For instance, Bommer and Jalajas [47] claim that "organizations with greater innovation will achieve a better response from the environment, obtaining more easily the capabilities 
needed to increase organizational performance and consolidate a sustainable competitive advantage". Garcia-Morales et al. [18] suggest that organizations "that concentrate on speed of innovation gain a greater market share which produces high income and high profitability". McMillan [49] denotes innovation brings efficiency and effectiveness - the two main criteria influencing success for long term survival.

On the study on American and European pharmaceutical firms, Garcia-Morales et al. [18] examines the effect of innovation on performance. The study depicts that innovation introduces new knowledge that is not made available to competitors at least for a certain period of time. The knowledge comes in the form of capabilities, resources and technologies and they are kept within the organization that adopts the innovation which intricate competitors to imitate. Aragon-Correa et al. [44] reiterates that organizations that adopt an innovation first are able to create "isolation mechanisms" as knowledge of the innovation is not available to competitors. This allows the organization to maintain its competitive advantage, protect profit margins and obtain greater organizational performance.

In the construction industry environment, Panuwatwanich et al. [8] explores the impact of innovation towards business performance in AED firms in Australia. The study concludes that innovation has a positive influence on performance. It is highlighted that in an industry where design is one of the critical elements, continually successful at developing and implementing innovation resulted in a positive perception of the organization by both clients and competitors.

These numerous studies in the innovation research field support the significance of innovation on enhancing performance as it offers better response to changing environment, gain greater market share, introduces new knowledge and established isolation mechanism for innovative organization. This highlights the fact that organizations that focus on improving innovation have greater chance in achieving greater performance. Nevertheless, despite the many researches in this field that provide evidences that the innovation-performance relationship is positive in nature, there are also evidences on the negative impact of innovation on performance. Such phenomenon is supported by Gunday et al. [31] who explain that the nature of innovation requires risky and expensive activities leading to increase exposure to market risk, increased costs, employee dissatisfaction or unwarranted changes that consequently provide negative impact on the overall organizational performance.

In a different study conducted by Wright, Palmer and Perkins [50], they indicate that innovation has a positive effect only on performance only in a hostile environment but not in a benign environment for small businesses. A hostile environment is characterized by intense rivalry among firms and weak or diminishing competitive opportunities. Firms operating in highly competitive (hostile) markets are likely to be more successful innovators by increasing the number of new product introductions through incremental innovation in order to meet customer needs hence contributing to the positive impact on performance.

These evidences indicate that there are conflicting outcomes of innovation-performance relationship studies which suggest more research on this complex relationship to be conducted. Moreover, the studies were not specific to the construction industry which further demands for in-depth understanding of the aspects of performance and innovation in the construction environment in Malaysia.

\section{Research Method}

\subsection{Research Objectives}

Given the above reviews, it is crucial to explore better understanding in the aspect of enhancing construction industry's performance which demands for dynamic and innovative strategies in contributing towards greater growth. Furthermore, the fact that there are gaps and concerns in the construction industry particularly in the context of industry's performance and innovation, an empirical study on the subject matter was proposed. In order to do so, innovation as the indicative determinants for organizational performance was explored and examined. Hence, this research aims bridge this gap by exploring the relationship between innovation and organizational performance in the context of the construction industry in Malaysia.

\subsection{Research Framework}

The theoretical framework of this research was developed based on the literature reviews of past researches discussed in the earlier part of this paper. The proposed framework (Figure 1) illustrates the logical relationship between the independent and dependent variables. The dependent variable - organizational performance is described by two dimensions - project performance and business performance. In this research, innovation is the independent variable and its impact to the organizational performance which is represented by three dimensions namely innovative design solutions, innovative project practices and advanced technology utilization is examined.

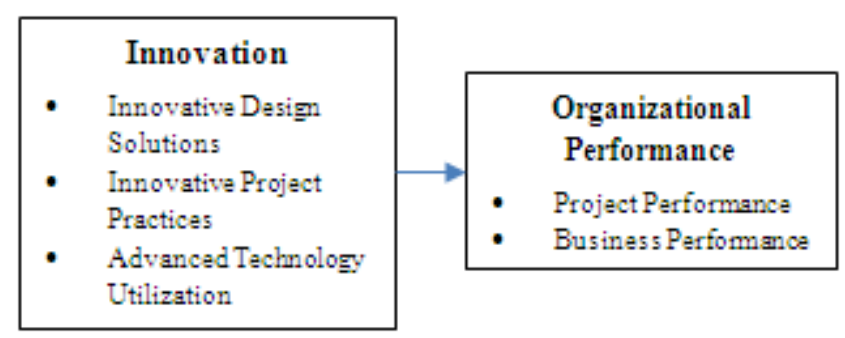

Figure 1. Research Framework

\subsection{Sample Data}

In Malaysia, organizations that involve in this industry are mainly contractors and consulting companies. Currently, there are 63,850 registered contractors in CIDB and since 
registration with CIDB is a compulsory requirement for the contractors to legally practice in Malaysia, these numbers can be considered valid to represent the population of contractors. The registered contractors are categorized into seven grades which represent the value of construction contracts they are eligible to participate in. The eligibility is based on certain technical and financial criteria set by CIDB (Table 1).

Table 1. Contractor's Grade

\begin{tabular}{cc}
\hline Grade & Maximum Contract Value \\
\hline G1 & Not exceeding 200,000.00 \\
G2 & Not exceeding 500,000.00 \\
G3 & Not exceeding 1 million \\
G4 & Not exceeding 3 million \\
G5 & Not exceeding 5 million \\
G6 & Not exceeding 10 million \\
G7 & No Limit \\
\hline
\end{tabular}

Source: CIDB [4]

The scope of this research is confined to contractors in grade G7, G6 and G5 only as they are involved in projects having a contract value of more than RM3 million. Projects below RM3 million are categorized as small projects and have limited scope and complexity [51] and are excluded in this study. This reduces the population list to 9,788 contractors. Table 2 below provides the summary of the population frame.

Table 2. Population Frame

\begin{tabular}{ccc}
\hline Organization & Source & $\begin{array}{c}\text { No. of Registered } \\
\text { Organizations }\end{array}$ \\
\hline G7 Contractors & CIDB & 4,573 \\
G6 Contractors & CIDB & 1,398 \\
G5 Contractors & CIDB & 3,817 \\
Engineering Consultants & BEM & 2,198 \\
Architectural Consultants & BOA & 1,609 \\
Quantity Surveyor & BQSM & 339 \\
Consultants & & 13,934 \\
\hline TOTAL &
\end{tabular}

On the other hand, the list of the Board of Engineers of Malaysia (BEM), reported 2,198 registered private engineering consulting companies in Malaysia. These companies are categorized based on their engineering disciplines namely civil, mechanical and electrical engineering. Board of Architect (BOA) registered 1,609 architectural consulting companies and 339 quantity surveyors consulting companies that are currently in the list of the Board of Quantity Surveyor (BQSM). The organizations mentioned above will be the population of this research. According to Sekaran [52], considering the size of the total population of 13,934 the number of sample required to represent the whole population is 375 . This is based on the population size up to 15,000 . Therefore, a minimum of 375 organizations is required as the research sample. These sample organizations will be selected from the population list based on the multi-staged stratified samplings in strata of contractors and consultants provided by CIDB, BEM, BOA and BQSM. These stratified groups are further divided into subgroups based on their categories characterized by the relevant professional bodies and is illustrated in Figure 2. This allows for a realistic representation of the total population of this research that consists of all relevant stakeholders of the industry.

The population were first stratified into two groups namely contractor and consultant. The two groups were further stratified into more specific groups of which contractors were stratified based on the CIDB registration categories - G5, G6 and G7 contractors and consultants were stratified into engineering (registered with BEM), architecture (registered with BOA) and quantity surveyor (registered with BQSM) discipline. Engineering consultant is further divided into two major disciplines - (1) civil and structure engineering, (2) electrical and mechanical engineering. Figure 2 illustrates the stratifications of the population.

Source: CIDB [4]

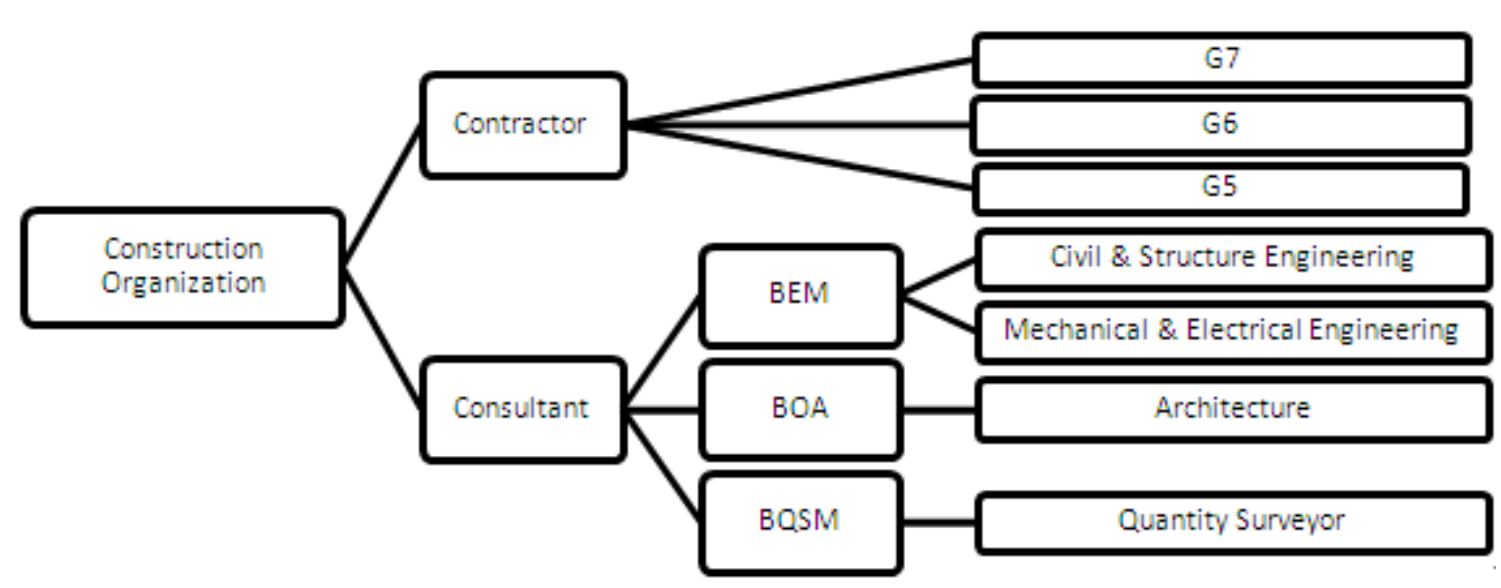

Figure 2. Stratification Stages 
A set of questionnaire survey was developed to elicit the responses of the respondents of this research. The data collection was conducted in the traditional personally administered approach whereby respondents are given a hard copy form of questionnaire and monitored face to face during the survey sessions. Selections of respondents among the stratified groups were then based on a simple random sampling method and a total of 378 responses were received. The grouping of the respondents is summarized in Table 3 .

Table 3. Respondents Grouping

\begin{tabular}{cc}
\hline Stratification Groups & Freq. \\
\hline G7 & 70 \\
G6 55 & 62 \\
Civil \& Structure & 66 \\
Mechanical and Electrical & 51 \\
Architecture & 43 \\
Quantity Surveyor & 47 \\
Total & 39 \\
\hline
\end{tabular}

\subsection{Variables and Measures}

\subsubsection{Organizational Performance}

The survey method was adopted in order to gather responses from the sample determined above. In this study, organizational performance is the dependent variable. It consists of two dimensions that are (1) project performance and (2) business performance. Each dimension consists of several statements that represent the elements of the respective performance indicators. Dess and Robinson [53] assert that there is a high correlation and concurrent validity between objective and subjective data on performance, which implies that both are valid when calculating an organization's performance. Hence, perceived measures of performance can be a valid substitute for objective performance measure and is adopted in determining the organizational performance in this research. For example, the elements of the business performance assess the respondent perception of the level of the performance of their organizations' as compared to their competitors.

Table 3 summarizes the operationalization of the organizational performance. Project performance dimension measurements are adapted from the work by Chan and Chan [41] and Almahmoud et al. [38]. The questions were adapted from the study by Pinto et al. [43] which include the environment and safety elements which bring to a total of ten items. The questions reflect elements of (1) Quality (2) Timeliness (3) Cost (4) Scope (5) Safety and Health (6) Environment (7) Participant's Satisfaction (8) User/client's Satisfaction (9) Value (10) Overall Success.

Business performance on the other hand reflect elements of (1) Profit growth (2) Turnover growth (3) Market share (4) New clients and (5) Repeat business (6) Level of customer satisfaction (7) Overall reputation. The elements will be compared and rated against the organization's competitors over the last three years. These measurement constructs is adapted from the study by Panuwatwanich et al. [8] and Gunday et al. [31].

\subsubsection{Innovation}

The instrument for measuring innovation in this study combines dimensions from several studies in the field of innovation specific to the construction industry environment. They were adapted from Bossink [54], Dubois and Gadde [55], Blayse and Manley [22], Dewick and Miozzo [56], Peansupap [23], Panuwatwanich et al. [8], and Qi et al. [25]. The instrument mostly adapted the constructs by Panuwatwanich et al. [8] which categorizes them into three dimensions which are (1) Innovative Design Solution, (2) Innovative Project Practice and (3) Advanced Technology Utilization. The dimensions included the whole aspects of construction project implementation that is not only the design aspect. The innovation design solution refers to the degree of the design innovativeness of the construction project. Although it relates much to the construction design aspects, it is adapted to include the involvement of contractors during the implementation stage. The innovative project practice dimension refers to the value-added process, which aims to enhance the project performance. The advanced technology utilization dimension refers to the adoption of advanced technology during the project implementation. Table 4 summarizes the variables represent every dimensions along with the associated adopted reference.

Table 4. Summary of Organizational Performance Measures

\begin{tabular}{ccc}
\hline Dimension & Elements & Adapted From \\
\hline & Quality & \\
& Timeliness & \\
Cost & \\
Scope & \\
Perfoject & Safety and Health & {$[38,41,43]$} \\
& Environment & \\
& Participant's Satisfaction & \\
& User/client's Satisfaction & \\
& Value & \\
& Overall Success & \\
\hline & Profit Growth & \\
Turnover Growth & \\
Performance & Market share & \\
& New clients & \\
& Repeat business & \\
& Level of customer & \\
& satisfaction & \\
& Overall reputation &
\end{tabular}

\section{Analysis and Findings}

The data collected from the surveys were analyzed using Statistical Package for Social Sciences (SPSS) Version 16.00 statistical software. Regression analyses were performed to analyze the relationships between two or more variables with dependent variable (multiple regressions), in this case, the 
relationships between innovation and organizational performance.

The underlying assumptions of the linear regression, which are linearity, normality and homoscedasticity were tested in continuous data used for the regression analysis. Linearity was assessed by analyzing the scatterplots of the variables, whilst histogram and skewness data were used to detect the normality of the variables. Consistent variance of the error term is associated with homoscedasticity. Homoscedasticity assumes that the dependent variable exhibits equal levels of variance across the range of predictor variables [57]. To determine if a relationship is homoscedastic is to analyze the scatter plot of the variables on the $\mathrm{x}$-axis and the variable's residual on the y-axis. The scatter plot that displays a specific pattern indicates homoscedasticity were met.

Analyses on the relationship of innovation and organizational performance were separately conducted based on the three defined dimensions of innovation and two dimensions of organizational performance. The $\mathrm{r}^{2}$ value and the Beta coefficient as well as its significance were analyzed and examined on all of the dimensions relationships as indicated in Table 5.
Table 5. Summary of Innovation measures

\begin{tabular}{|c|c|c|}
\hline Dimension & Elements & Adapted From \\
\hline $\begin{array}{c}\text { Innovation } \\
\text { design solution }\end{array}$ & $\begin{array}{c}\text { Recognition and awards } \\
\text { Flexibility of the design } \\
\text { Environmental sustainability } \\
\text { New and established } \\
\text { recognizable design }\end{array}$ & {$[8,23,25]$} \\
\hline $\begin{array}{c}\text { Innovative } \\
\text { project practice }\end{array}$ & $\begin{array}{c}\text { Value management } \\
\text { Value engineering } \\
\text { Life cycle costing } \\
\text { Constructability review } \\
\text { Sustainable } \\
\text { design/construction } \\
\text { Total Quality Management }\end{array}$ & {$[8,25]$} \\
\hline $\begin{array}{l}\text { Advanced } \\
\text { Technology } \\
\text { Utilization }\end{array}$ & $\begin{array}{c}\text { Advanced design drafting } \\
\text { techniques } \\
\text { Advanced project } \\
\text { procurement system } \\
\text { Advanced project monitoring } \\
\text { tools } \\
\text { Advanced technical products } \\
\text { Advanced construction } \\
\text { techniques } \\
\text { Environmental friendly } \\
\text { equipment and products } \\
\text { Advanced ICT application }\end{array}$ & $\begin{array}{c}{[8,22,23,54,55} \\
56]\end{array}$ \\
\hline
\end{tabular}

Table 6. Innovation and Organizational Performance

\begin{tabular}{|c|c|c|c|c|c|c|}
\hline \multirow{3}{*}{$r^{2}$} & \multicolumn{3}{|c|}{ Project Performance } & \multicolumn{3}{|c|}{ Business Performance } \\
\hline & \multicolumn{3}{|c|}{0.258} & \multicolumn{3}{|c|}{0.179} \\
\hline & $\begin{array}{l}\text { Std. Error of } \\
\text { the Estimate }\end{array}$ & $\begin{array}{l}\text { Sig. F } \\
\text { Change }\end{array}$ & Durbin-Watson & $\begin{array}{l}\text { Std. Error of the } \\
\text { Estimate }\end{array}$ & $\begin{array}{l}\text { Sig. F } \\
\text { Change }\end{array}$ & Durbin-Watson \\
\hline & 0.87581 & 0.000 & 1.824 & 0.921201 & 0.000 & 1.815 \\
\hline Variable & B & Std. Error & Sig. & B & Std. Error & Sig. \\
\hline (Constant) & 0.006 & 0.049 & 0.896 & -0.022 & 0.051 & 0.673 \\
\hline $\begin{array}{l}\text { Innovative Design } \\
\text { Solution }\end{array}$ & 0.119 & 0.054 & 0.029 & 0.048 & 0.057 & 0.405 \\
\hline $\begin{array}{c}\text { Innovative Project } \\
\text { Practice }\end{array}$ & 0.199 & 0.053 & 0.000 & 0.184 & 0.056 & 0.001 \\
\hline $\begin{array}{c}\text { Advanced Technology } \\
\text { Utilization }\end{array}$ & 0.094 & 0.051 & 0.067 & 0.199 & 0.054 & 0.000 \\
\hline
\end{tabular}


The $r^{2}$ value of the multiple regression analysis indicates that 25.80 percent of variation in project performance and 17.90 percent of variation in business performance are significantly $(\rho<0.001)$ explained by the innovation. The B scores of the two significant dimensions for project performance are ranked and modeled as the following:

$$
\mathrm{Y}=0.199 \mathrm{X}_{1}+0.119 \mathrm{X}_{2}+\varepsilon
$$

where

$\mathrm{Y}$ is Project Performance

$\mathrm{X}_{1}$ is Innovative Project Practice

$\mathrm{X}_{2}$ is Innovative Design Solution

$\varepsilon$ is Random Error Term

The analysis of the business performance establishes the following model:

$$
\mathrm{Y}=0.199 \mathrm{X}_{1}+0.184 \mathrm{X}_{2}+\varepsilon
$$

where

$\mathrm{Y}$ is Business Performance

$\mathrm{X}_{1}$ is Advanced Technology Utilization

$\mathrm{X}_{2}$ is Innovative Project Practice

$\varepsilon$ is Random Error Term

Based on the analysis, the dimensions of innovation namely innovative design solutions, innovative project practices and advanced technology utilization have been identified by the outcome of this study to have significant influence on at least one dimension of the organizational performance. Innovative project practices dimension is found to have significant influence on both project and business performance positively. On the other hand, while innovative design solution is found to significantly influence project performance, advanced technology utilization is indicated to significantly influence business performance positively also. Table7 provides the summary of the analysis outcomes.

Table 7. Summary of Analysis

\section{Significant Relationship}

\begin{tabular}{cc}
1.1 & Innovative Design Solution - Project Performance \\
1.2 & Innovative Project Practice - Project Performance \\
1.3 & Innovative Project Practice - Business Performance \\
1.4 & Advanced Technology Utilization - Business Performance \\
\hline & Insignificant Relationship \\
2.1 & Advanced Technology Utilization - Project Performance \\
2.2 & Innovative Design Solution - Business Performance \\
\hline
\end{tabular}

\subsection{Innovative Design Solution on Organizational Performance}

The outcome of this study indicates that innovative design solution is significant in influencing project performance. The finding is consistent with the past study by Panuwatwanich [8] which described the construction industry as "where design is one of the critical elements, continually successful at developing and implementing innovation resulted in a positive perception of the organization by both clients and competitors". Hence, justifies the significance of innovative design solutions on project performance.

However, it is found in this study that innovative design solution does not influence business performance. The relationship between innovative design solution and business performance that is not significant can be justified by the fact that innovative design in a construction project involves changes in the technical aspects that require endorsement by the relevant competent professionals. They are responsible for every design they endorsed and are held liable in any incident of fault due to design error. As a result, the innovative design solution may lead to increase of costs due to the demand for new expertise, introduction of new processes and exposure to higher risks; that consequently affects the organization's profit margin. Outcome of the findings of this study is also supported by a study by Gunday et al. [31].

\subsection{Innovative Project Practice on Organizational Performance}

The main objective of innovative project practices is to introduce greater effectiveness in construction project implementation. This is very crucial as many scholars highlighted the poor performance of the industry in terms of fulfilling the project performance criteria [1, 58]. The elements of project practices such as value management, value engineering, total quality management, sustainable design, constructability review and lifecycle costing are proven in this study to have positive impact on the organizational performance. For example, the value engineering practice is aimed to increase the value of a construction project by improving the function of the components of the project. This can be reflected in the positive outcome of the project performance as such approach relatively reduces the project cost by improving project scope. The constructability review for instance aimed at facilitating efficient use of construction resources in terms of equipment, material and labor that will be reflected in improved business performance. This shows that consistent application of innovative project practices allows for organization to achieve organizational performance both in the aspect of project and business performance. Hence, explains the outcome of this research.

\subsection{Advanced Technology Utilization on Organizational Performance}

Advanced technology utilization is revealed in this study to have a significant influence only on the business performance of construction organization but not on project performance. In comparison with the innovative design solutions, utilizing advanced technology generate lesser uncertainties as such innovation initiative involves adopting available technologies into the organization. Prior to the decision to utilize an advanced technology, an organization has the opportunity to evaluate the technology. These 
technologies may have been successfully implemented by other organizations and the possible effects on an organization to adopt such technology can be evaluated and hence reduces the possible risks. Consequently, the aim for utilizing a new technology is to develop efficiency and effectiveness that eventually leads to greater business performance. Chan and Sundaraj [59] support the outcome of this study by highlighting the ineffectiveness and low productivity of organizations in construction industry are caused by the failure of the industry to utilise the new as well as other relevant labour-reducing technologies.

In the context of project performance, according to Garcia and Calantone [60] the benefits of technological innovation depend on the extent to which these technologies are actually used. Advanced technologies aim to offer more efficient and effective approaches in project implementation which provide the means for construction organization in achieving superior project performance. However, new technologies demand skills and expertise in using them and without such expertise the technology may not be utilized appropriately which leads to delays, high accident cases, technology breakdowns and material wastages that will ultimately jeopardize project performance. Furthermore, the positive effect of adopting new technology is mostly reflected to the organization in the long run. However, in short term, adopting a new technology requires increase in project cost, as it demands capital expenditure in purchasing such technology and employing technology experts which reflect in the overall project performance of the current project. Hence, explains that utilizing advanced technology does not necessarily lead to achieving superior project performance which is the outcome of this study.

\section{Conclusions}

By drawing attention to the aspects of innovation and uncovering the mechanisms for enhancing organizational performance, this study sheds additional light on the implications of fostering innovation within the construction industry context. This study highlights the importance of organizations in this industry to focus on promoting innovation as it is critical in determining organizational performance. However, the study revealed that in the context of construction industry, the types of innovation ventured by the organization have different impact on the project performance and business performance. Nevertheless, the significance of innovation in influencing organizational performance provides a new phenomenon in the industry that has been labeled as matured and delayed in innovative effort. Although there is an increasing awareness of the importance of innovation, to date studies on it in Malaysia are very scarce. The Malaysian environment and industry setup of this research provides relevant knowledge for future studies for cross-cultural and cross-industry comparison on innovation.

\section{REFERENCES}

[1] Ibrahim, A.R, Roy, M.H, Ahmed, Z, Imtiaz, G. An investigation of the status of the Malaysian construction industry. Benchmarking: An International Journal 2010; 17(2): 294-308.

[2] PEMANDU. The Economic Transformation Program. http://www.pemandu.gov.my/en/rural-basic-infrastructure/60 0.html (accessed 25 September 2011).

[3] EPU. Malaysia Economy (2010). http://www.epu.gov.my/ malaysianeconomyfigures2010 (accessed 5 July 2010).

[4] CIDB. Construction Quarterly Statistical Bulletin 2010. http://www.cidb.gov.my (accessed 21 October 2013).

[5] Barlow, J. Innovation and learning in complex offshore construction projects. Research Policy 2000; 29 (7/8): 973-989.

[6] Doree, A.G. Collusion in the Dutch construction industry: an industrial organization perspective. Building Research and Information 2004; 32(2): 146-156.

[7] Sexton, M., Barret A. A literature synthesis of innovation in small construction firm: insight, ambiguities and questions. Construction Management and Economics 2003; 21(6): 613-622.

[8] Panuwatwanich, K., Stewart, R.A, Mohamed, S. Critical pathways to enhanced innovation diffusion and business performance in Australian design firms. Automation in Construction 2008; 18(1): 790-797.

[9] Stewart, R.A., Mohamed, S. Marosszeky, M. An empirical investigation into the link between information technology implementation barriers and coping strategies in the Australian construction industry. Construction Innovation 2004; 4(3): 155-171.

[10] Salter, A., Gann, D. Sources of ideas for innovation in engineering design. Research Policy 2003; 32(1), 1309-1324

[11] Wan, D., Ong, C.H., Lee, F. Determinants of firm innovation in Singapore. Technovation, 2005; 25(1), 261-268.

[12] Ismail, M. Creative climate and learning organization factors: their contributing towards innovation. Leadership \& Organizational Development Journal 2005; 26(8), 639-654.

[13] Jaafar, M., Ramayah, T., Abdul-Aziz, AR., Saad, B. Technology readiness among managers of Malaysian construction firm. Engineering, Construction and Architectural Management 2007; 14(2), 80-191.

[14] Yitmen, I. The challenge of change for innovation in construction: A North Cyprus perspective. Building and Environment 2007; 42(1), 1319-1328.

[15] NESTA. Hidden Innovation. London: National Endowment for Science, Technology and the Arts; 2007.

[16] Abott, C., Jeong, K. The economic motivation for innovation in small construction companies. Construction Innovation 2006; 6(1), 187-196.

[17] Thorpe, D., Neal, R., Charles, M. Innovation and small 
residential builders: an Australian study. Construction Innovation 2009; 9(2), 184-200.

[18] Gracia-Morales, V.J. Influence of transformational leadership on organizational innovation and performance depending on the level or organizational learning in the pharmaceutical sector. Journal of Organizational Change Management 2008; 21(2), 188-212

[19] Woodhead R. Can any facilitator run a value engineering workshop? The RICS Construction and Building Research Conference: COBRA'98, 1998; RICS Research, London

[20] Aouad, G., Ozorhon B., Abbott, C.. Facilitating innovation in construction. Construction Innovation 2010; 10(4), 374-394.

[21] Slaughter, S.E. Models of construction innovation. Journal of Construction Engineering and Management 1998; 124(3), 226-31.

[22] Blayse, A.M., Manley, K. Key influences on construction innovation. Construction Innovation 2004; 4(1), 143-154.

[23] Peansupap, V., Walker, D. Factors affecting ICT diffusion: a case study of three large Australian construction contractors, Engineering, Construction and Architectural Management 2005; 12(1), 21-37.

[24] Gil, N. Miozzo, M., Massini, S. The innovation potential of new infrastructure development: An empirical study of Heathrow airport's T5 project. Research Policy 2012; 41(1), 453-466.

[25] Qi, G.Y., Shen, L.Y., Zeng, Jorge, S.X. The drivers for contractors' green innovation: an industry perspective. Journal of Cleaner Production 2010; 18(14), 1358-1365

[26] Buysse, K., Verbeke, A. (2003), Proactive environmental strategies: a stakeholder management perspective. Strat. Mgmt. J. 2003; 24(1), 453-470.

[27] Kotter, J. P. Leading Change. Boston: Harvard Business School Press; 1996

[28] Bhatti, W.A., Khan, M.N., Ahmad, A., Hussain, N., Rehman, K. (2011). Sustaining Competitive Advantage through effective knowledge management, African Journal of Business Management 2011; 5(8), 3297-3301.

[29] Popova, V., and Sharpanskykh, A. Modeling Organizational Performance Indicators, Information Systems Journal 2010; 35(4), 505-527.

[30] Robinson, H.S. Carrillo, P.M. Anumba, C.J., A-Ghassani, A.M. Review and implementation of performance management models in construction engineering organizations, Construction Innovation: Information, Process, Management 2005; 5(4), 203 - 217

[31] Gunday, Ulusoy, Kilic, Lutfihak. Effects of innovation types on firm performance. International Journal of Production Economics 2011; 133 (2). 662-676.

[32] PMI. A Guide to the Project Management Body of Knowledge: (Pmbok Guide). Project Management Institute; 2013.

[33] Westerveld, E. The Project Excellence Model: linking success criteria and critical success factors. International Journal of Project Management 2003; 21(6), 411-418.

[34] Atkinson, R. Project Management : Cost, Time and Quality,
Two Best Guesses and a Phenomenon, Its Time to Accept Other Success Criteria, International Journal of Project Management 1999; 17(6), 337-342.

Belassi, W., Tukel, O.I. A new framework for determining critical success/failure factors in projects. International Journal of Project Management 1996; 14(3), 141-51.

[35] Hatush, Z., Skitmore, M. Contractor selection using multicriteria utility theory: An additive model. Building and Environment 1997; 33(2-3), 105-115.

[36] Phua, F. T. T. The antecedents of co-operative behavior among project team members: an alternative perspective on an old issue. Construction Management and Economics 2004; 22(10), 1033 - 1045.

[37] Low, S. P., Chuan, Q. T. Environmental factors and work performance of project managers. International Journal of Project Management 2006; 21(1), 24-37.

[38] Almahmoud, Doloi, Puwatwanich. Linking project health to project performance indicators: Multiple case studies of construction projects in Saudi Arabia. International Journal of Project management 2011. 30(3), 296-307.

[39] Kometa, S.T., Olomolaiye, P.O., Harris, F.C. Attributes of UK construction clients influencing project consultant performance. Construction Management Economics 1994; $12(1), 433-443$

[40] Dulaimi, M.F., Ling, F.Y.Y, Ofori. Engines for change in Singapore's construction industry: an industry view of Singapore's Construction 21 report. Building and Environment 2004; 39(1) 699-711.

[41] Chan, A. and Chan, E. Impact of perceived leadership styles on work outcomes: case of building professionals, Journal of Construction Engineering and Management 2005; 13(1), 413-22.

[42] Nudurupati, S., Arshad T. and Turner T. Performance measurement in the construction industry: An action case investigating manufacturing methodologies. Computers in Industry 2007; 58(1) 667-676.

[43] Pinto, J. K., D. Slevin, B., English. Trust in Projects: An Empirical Assessment of Owner/Contractor Relationships. International Journal of Project Management 2009; 27(6), 638-648.

[44] Aragon-Correa, J.A., Garcia-Morales, J.V., Cordon-Pozo, E. Leadership and organizational learning's role on innovation and performance: Lesson from Spain. Industrial Marketing Management 2007; 36(1), 349-359.

[45] Cheng, E.W.L, Ryan, Kelly, S. Exploring the perceived influence of safety management practices on project performance in the construction industry. SSC Journal Publications 2012; 50(2), 363-369.

[46] Beach R., Webster, M., Campbell, K.M. An evaluation of partnership development in the construction industry. International Journal of Project Management 2005; 23(1) 611-621.

[47] Bommer, M., Jalajas, D.S. Innovation sources of large and small technology-based firms. Engineering Management 2004; 51(1), 13-18.

[48] Chen, C., Huang, J. Strategic human resource practices and 
innovation performance - The mediating role of knowledge management capacity. Journal of Business Research 2009; 62(1), 104-114.

[49] McMillan, C. Five Competitive forces of effective leadership and innovation. Journal of Business Strategy 2010; 31(1), $11-22$.

[50] Wright, R.E., Palmer, J.C, Perkins, D. Type of product innovation and small business performance in hostile and benign environment. Journal of Small Business Strategy $2005 ; 15(2), 33-44$.

[51] PWD. Public Works Department. http://www.jkr.gov.my (accessed 28 February 2012).

[52] Sekaran, U. Research Methods for Business. A Skill Building Approach. John Wiley \& Sons, Inc. 2007.

[53] Dess GG, Robinson RB Jr. Measuring organizational performance in the absence of objective measures: The case of the privately-held firm and conglomerate business unit. Strategic Management Journal 1984; 5(1), 265-273.

[54] Bossink, B. Effectiveness of innovation leadership styles: a manager's influence on ecological innovation in construction project. Construction Innovation 2004; 4(1), 211-228.
[55] Dubois, A. and Gadde, L.-E. (2002), The construction industry as a loosely coupled system: implications for productivity and innovation, Construction Management and Economics 2002; 20(1), 621-31.

[56] Dewick, P. and Miozzo, M. Networks and innovation: sustainable technologies in Scottish social housing, R\&D Management 2004; 34(3), 323-33.

[57] Hair, J. F. Jr. Black, W. C., Babin, B. J. Anderson, R. E., Tatham, R. L. Multivariate data analysis. 6th ed. New Jersey: Prentice Hall; 2006.

[58] Abdul Rahman, H., Berawi, M. A., Berwai, A. R., Mohamed, O., Othman, M., Yahya, I. A. Delay mitigation in the Malaysian construction industry. Journal of Construction Engineering and Management 2006; 132(2), 125-33.

[59] Chan, T.K., Sundaraj, G. Performance measures for the Malaysian Construction Industry Development Board. In: Dainty, A. (Ed) Procs 25th Annual ARCOM Conference, 7-9 September 2009, Nottingham, UK, Association of Researchers in Construction Management 2009, 371-379.

[60] Garcia, R., Calantone, R. A critical look at technological innovation typology and innovativeness terminology: a literature review. Journal of Product Innovation Management 2002; 19(1), 110-132. 